\title{
DIVORCE AND HOUSING PRICE IN 31 PROVINCES OF CHINA
}

\author{
Mingbo Zheng, ${ }^{1}$ Yin E Chen ${ }^{2}$, Gen-Fu Feng ${ }^{1}$, Jun Wen ${ }^{1}$, Chun-Ping Chang ${ }^{3}$ \\ ${ }^{1}$ School of Economics and Finance, Xi'an Jiaotong University, Shaanxi, China. \\ ${ }^{2}$ School of Economics and Management, Changsha University of Science \& Technology, \\ Changsa, China. \\ ${ }^{3}$ Shih Chien University, Kaohsiung, Taiwan. Email: cpchang@g2.usc.edu.tw
}

\begin{abstract}
This paper investigates the long-run cointegration relationship between housing price and divorce in China using panel data for 31 provinces over the period 1997-2015. We find that housing price and divorce have the long-run cointegrated relationship in the full samples, in the short run, housing price has a positive effect on divorce in the whole country, particularly the Eastern region. For the long run, the reverse effect is discovered in the full sample and Eastern region. These results are robust once we use the residential housing price as an alternative variable. Our finding suggests that the government should take the short-run housing price regulation to slowdown the divorce rate.
\end{abstract}

Keyword: Divorce; Housing price; Panel cointegration test; FMOLS.

JEL Classification: D1; J12; R21.

Article history:

Received : July 5, 2018

Revised : : September 23, 2018

Accepted : : September 28, 2018

Available online : October 31, 2018

https://doi.org/10.21098/bemp.v21i1.942 


\section{INTRODUCTION}

"Couples in one Chinese city are increasingly faking divorce to cheat property purchase restrictions, with some pretending to separate seven times to buy a new house, according to People's Daily. ... The practice of faking divorce has become widespread with many reportedly admitting the sole purpose was just to purchase a property with lower taxes." ${ }^{4}$

China witnessed soaring housing prices, rising from 2,112 to 5,032 yuan per square meter over the period $2000-2010$ ( $\mathrm{Li}$ and $\mathrm{Wu}, 2014)$, resulting in a number of peculiar phenomena, including a reduced savings rate and a lower fertility rate ( $\mathrm{Li}$ and $\mathrm{Xu}, 2012$; $\mathrm{Li}$ et al., 2013). Accompanying the huge change in housing prices and economic development, China's divorce rate has dramatically increased since the reform and opening-up policy was initiated in 1978 (Wang and Zhou, 2010). The divorce rate (number of divorces per 1000 people) increased from 0.97 in 1997 to 2.79 in 2015. A natural issue arises: do housing prices and the divorce rate move together in China? Fan and $\mathrm{Hu}$ (2015) find that unexpected housing price fluctuations exert a shock on the divorce rate. Wang (2018) demonstrates that the divorce rate has a positive effect on housing prices based on provincial data in China. Exploiting national-level time series data, $\mathrm{Yu}$ and Zhou (2015) show that there is a cointegration relation between housing price and divorce rate. Nevertheless, whether the cointegration relationship exists for the provinces of China remains an unsolved issue. Given the considerable differences in economic development level and cultural tradition among provinces, the housing price-divorce relationship requires further investigation at the provincial level.

The panel-based cointegration test allows for heterogeneous coefficients among individuals and provides powerful statistics. Hence, the objective of this paper is to examine the long-run relationship between housing price and divorce rate in China. Using the panel cointegration test proposed by Pedroni (2004) and Westerlund (2005), we investigate the long-run cointegration relationship between housing price and divorce rate for panel data for 31 provinces in China over the period of 1997-2015. Furthermore, we employ the panel fully modified ordinary least squares (FMOLS) to estimate the long-run equations and the panel-based vector error correction model (VECM) to distinguish short-run and long-run causalities between housing price and divorce rate. Moreover, we divide all provinces into three subsamples (the eastern, central, and western regions) and check whether the cointegration relationship exists in each subsample. To check for the robustness of our results, we use residential housing price to re-examine the cointegration relationship.

Many researchers hold that house demand plays an important role in determining housing price ( $\mathrm{Li}$ and Chand, 2012; Zhang et al., 2012). One of the factors affecting housing demand is the divorce rate. A higher divorce rate may result in a higher housing price by creating more households and more housing demand (Dieleman and Schouw, 1989). Wei and Zhang (2011) propose that the imbalance of sex ratio in China forces Chinese households to save money to

\footnotetext{
4 A comment published in the website of China Daily, concerning a couple's fake divorce to cheat on housing regulations. http://www.chinadaily.com.cn/china/2012-12/19/content_16032812.htm
} 
improve their children's competitive advantages in the marriage market. Further, this gender imbalance increases housing price through higher saving rates, given that a house is recognized as a status good (Wei et al., 2017). Thus, divorce increases the demand for marriage and thus the demand for housing, implying a positive effect on housing price.

Since the pioneering work of Becker et al. (1977), the literature has documented that economic conditions, especially wealth shocks, influence marital stability (Boheim and Ermisch, 2001). Hence, Mused (2009) argues that changes in housing price significantly affect the probability of marital dissolution, which supports the proposition by Becker et al. (1977) that changes in wealth influence the decision on divorce. As Harknett and Schneider (2012) find, negative macroeconomic conditions (like recession) make couples delay the process of marital separation. Moreover, Weiss and Willis (1997), Rainer and Smith (2010) as well as Battu et al. (2013) find that housing price increases the risk of partnership dissolution. Conversely, Farnham et al. (2011) reach the reverse conclusion. Klein (2017) proposes that changes in housing prices present positive shocks to marital stability in families in the United States. For developing countries, Farzanegan and Gholipour (2016) exploit data for Iran and find that higher housing cost leads to a decline in marital stability. Fereidouni (2016) also show that there is a positive link between housing price and divorce rate in the Middle East and North Africa. Therefore, the effects of housing price on divorce remain a debatable question in the existing empirical literature. Our paper thus attempts to contribute to better understanding this issue by using the cointegration test and panel-based causality test.

As Becker et al. (1977) points out, a couple chooses to marry if the expected utility of marriage exceeds the utility of remaining single. Once the outside environment changes the gains of marriage, a couple will consider the divorce option. As Klein (2017) argues, unexpected housing price change could affect the decision of couples in the opposite direction. On the one hand, an increase in the wealth of a household (house price) means higher consumption and lower financial stress (Attanasio et al., 2011), which improves marital satisfaction and reduces the risk of divorce. On the other hand, a rapid increase in housing prices generally makes the sale of houses easier for couples on the verge of divorce (Genesove and Mayer, 1997), which increases the probability of divorce by reducing the cost of divorce and making life easier for each person (Klein, 2017).

Based on the panel provincial data, we find that there is a cointegrated relationship between housing price and divorce in the full sample. The subsample analysis also indicates that the cointegration relation exists in all subsamples. The panel VECM shows that in the short-run, housing price has a positive effect on divorce in the whole country and the eastern region. However, in the long-run, the reverse effect is discovered in the full sample and the eastern region. The results are robust using residential housing price as an alternative variable. Hence, our results confirm the cointegration relationship between housing price and divorce in China.

The remainder of this paper proceeds as follows. Section II describes the model and data source. Section III provides the empirical results. Finally, Section IV sets forth our conclusions. 


\section{DATA AND MODEL}

Our study uses panel data for 31 provinces in China over the period 1997-2015. Following Liang et al. (2016), we measure housing price via average housing price per square meter (Hprice). The data were obtained from China National Knowledge Infrastructure. For divorce rates, we calculate the number of divorce registrations divided by total population (Divorce) to measure the level of provincial divorce rates. The data were collected from the National Bureau of Statistics of China (NBS). The trends of national housing price and divorce are plotted in Figure 1. Note that housing price and divorce rate manifest similar rising trends, suggesting that a cointegration relationship between housing price and divorce rate may exist in China. We also present the descriptive statistics in Appendix Table A1. The mean of Divorce is 6.855 in our sample provinces, reflecting a high divorce rate in China. The standard deviations of Divorce are relatively high, suggesting that the divorce rate varies across provinces and time. We also observe that average housing price (Hprice) is 3,581 yuan per square meter during the sample period.

\section{Figure 1. Housing Price and Divorce in China (1997-2015)}

The figure shows the relationship between housing price and divorce in China (1997-2015). Housing Price is the national average housing price per square meter. Divorce is the number of divorce registrations divided by total population (per thousand people).

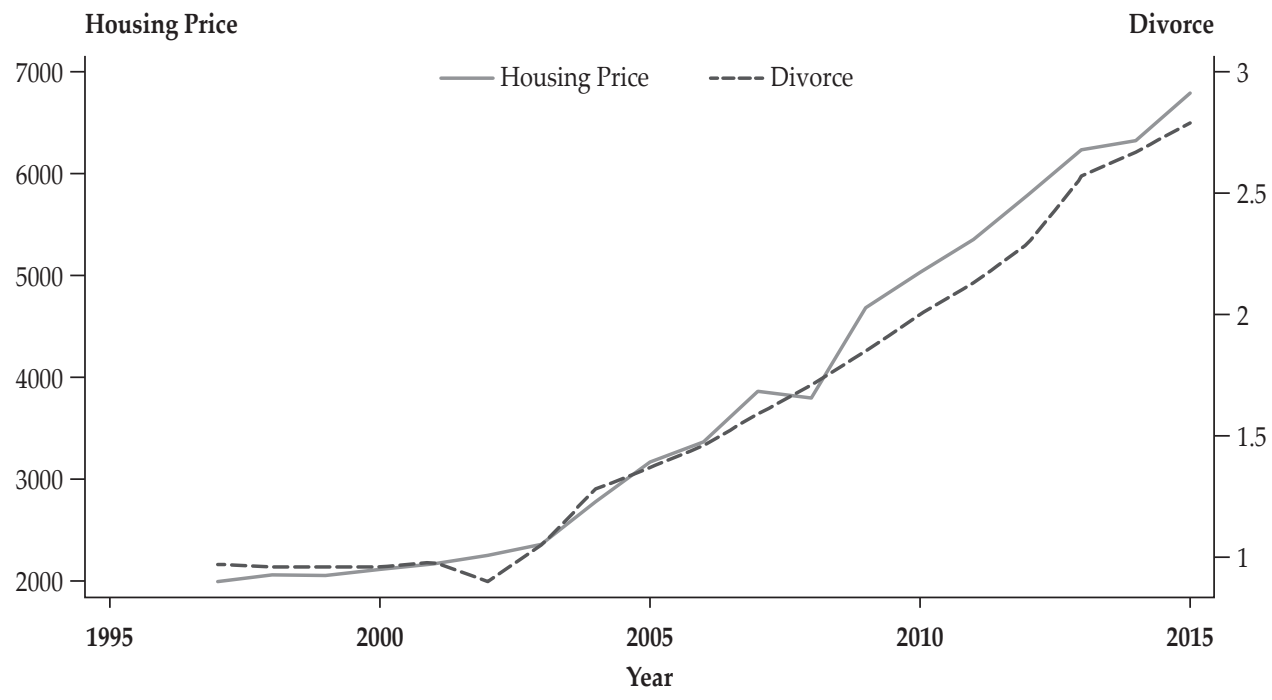

To investigate the long-run relationship of housing price and divorce in China, we employ the panel cointegration test proposed by Pedroni (2004), which takes the following form:

$$
y_{i t}=\alpha_{i}+\phi_{i} t r+x_{i t}^{\prime} \beta_{i}+\delta_{i} c_{2010}+u_{i t}
$$


where $y_{i t}$ is the dependent variable, Divorce, $x_{i t}$ represents Hprice, tr represents the time trend, $\alpha_{i}$ corresponds to the provincial-specific fixed effect, $u_{i t}$ is the error term, $i$ denotes a province, and $t$ denotes a year. $c_{2010}$ is a dummy variable that equals 1 if year is greater than 2009 and 0 otherwise; this controls for a housing price regulation change in 2010. To account for the effect of regulation change on the cointegration relationship, we add this variable in the cointegration test and FMOLS model. As Pedroni (2004) mentions, there are seven statistics for the test results, including panel variance, panel $\rho$-statistic, panel PP-statistic, panel ADF-statistic, group $\rho$-statistic, group PP-statistic, and group ADF-statistic. Note that there are two advantages in the cointegration test proposed by Pedroni (2004). First, the short dynamics and the long-term slope coefficients are permitted to be heterogeneous among the individual members of the panels (Chang and Lee, 2015). Second, different individual fixed effects and time trends are allowed (Jang and Chang, 2014). To enhance the reliability of the cointegration test, we further use the cointegration test proposed by Westerlund (2005), which has the advantages of avoiding any correction for temporal dependencies of data, and it expresses excellent asymptotic characteristics, even in very small sample. ${ }^{5}$

If a cointegrated relationship among the variables is determined, then one can next estimate the cointegrated vectors by using the FMOLS estimation technique (Pedroni, 2000). Furthermore, once confirming the cointegration relationship and obtaining the results, we then establish the panel VECM to investigate short-run and long-run causality between housing price and divorce (Wen et al., 2017). We employ the two-step procedure proposed by Engle and Granger (1987). First, we run the regression in equations (2) and (3) to obtain the residual $u_{i t}$ and $\varepsilon_{i t}$ (error correction term; EM henceforth).

$$
\begin{aligned}
& \text { Divorce }_{i t}=\alpha_{1 i}+\beta_{1 i} t r+\chi_{1 i} \text { PPrice }_{i t}+\delta_{1} c_{2010}+u_{i t} \\
& \text { HPrice }_{i t}=\alpha_{2 i}+\beta_{2 i} t r+\chi_{2 i} \text { Divorce }_{i t}+\delta_{2} c_{2010}+\varepsilon_{i t}
\end{aligned}
$$

The second step is to estimate the panel Granger causality model with the dynamic error correction term, as follows:

$$
\begin{aligned}
& \Delta \text { Divorce }_{i t}=\sigma_{1 i}+\lambda_{1 i} \text { EM }_{i t-1}+\sum_{k} \gamma_{1 k} \text { DDivorce }_{i t-k}+\sum_{k} \varphi_{1 k} \Delta \text { HPrice }_{i t-k}+\eta_{1} c_{2010}+\omega_{i t} \\
& \Delta \text { HPrice }_{i t}=\sigma_{2 i}+\lambda_{2 i} \text { EM }_{i t-1}+\sum_{k} \gamma_{2 k} \Delta \text { Divorce }_{i t-k}+\sum_{k} \varphi_{2 k} \Delta \text { HPrice }_{i t-k}+\eta_{2} c_{2010}+v_{i t}
\end{aligned}
$$

Thus, by testing the significance of the coefficients of explanatory variables in equations (4) and (5), we can identify short-run and long-run causality between divorce and housing price (Chang et al., 2015). For short-run causality, we test

5 Note that the cointegration test proposed by Pedroni (2004) and Westerlund (2005) has some limitations on dealing with cross-sectional dependency. 
$\mathrm{H} 0: \phi_{1 k}=0$ for all $\mathrm{k}$ in equation (4) or $\mathrm{H} 0: \gamma_{1 k}=0$ for all $\mathrm{k}$ in equation (5). Thus, we check the significance of the speed of adjustment $\lambda$ to examine long-run causality. For long-run causality, we test H0: $\lambda_{1 i}=0$ for all $i$ in equation (4) or H0: $\lambda_{2 i}=0$ for all $i$ in equation (5). Furthermore, we use the joint test to check for long-run causality as a strong test (Chang et al., 2011).

\section{RESULTS}

First, the panel unit root test we use are the Breitung (Breitung, 2000), the LLC (Levin et al., 2002), and the IPS (Im et al., 2003). To avoid test distortion induced by cross-sectional dependence, following Levin et al. (2002), we remove the means of cross-sectional units before performing the panel unit root test. ${ }^{6}$ Table 1 presents the results of the panel unit root test, indicating that the levels of Hprice and Divorce have a unit root. Furthermore, we test whether the first difference of variables shows stationarity. The results show that the hypothesis of unit root can be rejected at the $1 \%$ level for all variables after they are first differenced. These results show that both Hprice and Divorce are in $\mathrm{I}(1)$ process.

Table 1.

\section{Panel Unit Root Tests}

The table reports the results based on the panel unit root tests. LLC, Breitung and IPS tests represent Levin et al. (2002), Breitung (2000) and Im et al. (2003) panel unit root tests, respectively, which are under the null of without a unit root. $\Delta$ denotes first differences. ${ }^{* * *}$ indicates statistical significance at the $1 \%$ level.

\begin{tabular}{lccc}
\hline Variable & LLC & Breitung & IPS \\
\hline Divorce & 4.007 & 6.337 & 9.852 \\
Hprice & 1.689 & 0.964 & 3.778 \\
DDivorce & $-6.348^{* * *}$ & $-10.360^{* * *}$ & $-8.958^{* * *}$ \\
$\Delta$ Hprice & $-7.541^{* * *}$ & $-9.098^{* * *}$ & $-11.543^{* * *}$ \\
\hline
\end{tabular}

To correct bias induced by reverse causality and serial correlation in the ordinary least square (OLS) model, as well as to examine the long-term relationship between housing price and divorce, we test Hprice and Divorce for cointegration. Table 2 provides results for the panel cointegration tests for the full sample (column 1) and the three subsamples: the eastern, central, and western regions, from columns 2 through 4, respectively. ${ }^{7}$ We first confirm that the cointegration relationship between housing price and divorce does exist in the full sample, no matter

6 We are grateful to the reviewer for providing this suggestion on controlling cross-sectional dependence.

7 Eastern region: Beijing, Fujian, Guangdong, Hebei, Jiangsu, Liaoning, Shandong, Shanghai, Guangxi, Tianjin, and Zhejiang, Hainan. Central region: Anhui, Henan, Heilongjiang, Hubei, Hunan, Jiangxi, Inner Mongolia, Jilin, and Shanxi. Western region: Chongqing, Gansu, Guizhou, Ningxia, Shaanxi, Qinghai, Sichuan, Xinjiang, Yunnan and Tibet. 
whether for the cointegration test of Pedroni (2004) or that of Westerlund (2005). For the eastern region, there is slightly weaker evidence based on the statistics from Pedroni (2004): only two statistics support the cointegration relationship. However, the Westerlund statistics show that the cointegration relation exists. In the central and western regions, five out of seven statistics from Pedroni (2004) reject the null of no cointegration, while the Westerlund statistics accept it. Overall, we see that housing price and divorce move together in the long-run in these four cases (Chang and Lee, 2010).

Table 2.

\section{Panel Cointegration Tests}

The table reports the results of the panel cointegration tests. The test statistics are from Pedroni's (2004) except for Westerlund that is from Westerlund (2005). Statistics are asymptotically distributed as normal. The variance ratio test is right-sided, while the others are left-sided. Hprice denotes housing price. ${ }^{* * * *+}$, and "denote rejecting the null of no cointegration at the $1 \%, 5 \%$, and $10 \%$ levels, respectively.

\begin{tabular}{lcccc}
\hline \multirow{2}{*}{ Variable } & \multicolumn{3}{c}{ Dependent Variable: Hprice } \\
\cline { 2 - 5 } & Full Sample & Eastern & Central & Western \\
\hline Panel variance & $4.344^{* * *}$ & 1.432 & $3.485^{* * *}$ & $3.233^{* * *}$ \\
Panel r & 0.242 & 1.289 & -0.358 & -1.032 \\
Panel PP & $-5.007^{* * *}$ & -0.375 & $-3.861^{* * *}$ & $-5.680^{* * *}$ \\
Panel ADF & $-5.921^{* * *}$ & -1.517 & $-3.902^{* * *}$ & $-5.233^{* * *}$ \\
Group r & $2.112^{* *}$ & $2.369^{* *}$ & 0.738 & 0.423 \\
Group PP & $-6.402^{* * *}$ & -1.439 & $-4.078^{* * *}$ & $-5.826^{* * *}$ \\
Group ADF & $-6.177^{* * *}$ & $-2.188^{* *}$ & $-3.533^{* * *}$ & $-5.126^{* * *}$ \\
Westerlund & $-1.758^{* *}$ & $-1.440^{*}$ & -0.598 & -0.95 \\
\hline
\end{tabular}

Table 3 gives province-by-province results and the panel FMOLS estimators. As shown at the bottom of Table 3, the panel parameters are statistically significant at the $1 \%$ level and positive, no matter whether the dependent variable is Hprice or Divorce. Similar evidence is found in the three subsamples. The results of panel parameters confirm the cointegration relationship again. On a provincial basis, housing price has a significantly positive effect on divorce rate, and reverse causality is found. When the dependent variable is Divorce, in 29 of 31 provinces (except for Tibet and Xinjiang) Hprice has a significantly positive effect on Divorce. When the dependent variable is Hprice, in all provinces divorce has a significantly positive effect on housing price. Peteke and Maarten (2010) argued that people experience a drop in housing quality after a divorce, which may offset the positive effect of housing price on divorce. Based on these results, there is little doubt that a stable cointegration relationship exists between housing price and divorce. 
Table 3.

FMOLS Long-Run Estimates: Divorce vs. Hprice

The table reports the long-run estimates. Hprice denotes housing price. ${ }^{*+*},{ }^{* *}$, and ${ }^{*}$ denote rejecting the null of no cointegration at the $1 \%, 5 \%$, and $10 \%$ levels, respectively.

\begin{tabular}{|c|c|c|}
\hline Province & $\begin{array}{c}\text { Dependent Variable: } \\
\text { Divorce }\end{array}$ & $\begin{array}{c}\text { Dependent Variable: } \\
\text { Hprice }\end{array}$ \\
\hline Beijing & $0.07(2.12)^{* *}$ & $5.27(2.07)^{* *}$ \\
\hline Tianjin & $0.23(5.84)^{* * *}$ & $3.56(5.25)^{* * *}$ \\
\hline Hebei & $0.44(7.36)^{* * *}$ & $2.04(8.82)^{* * *}$ \\
\hline Shanxi & $0.29(6.03)^{* * *}$ & $2.61(5.68)^{* * *}$ \\
\hline Inner Mongolia & $0.63(5.24)^{* * *}$ & $1.19(4.65)^{* * *}$ \\
\hline Liaoning & $0.50(8.97)^{* * *}$ & $1.61(9.43)^{* * *}$ \\
\hline Jilin & $0.92(5.59)^{* * *}$ & $0.80(7.18)^{* * *}$ \\
\hline Heilongiiang & $0.90(15.03)^{* * *}$ & $1.05(16.01)^{* * *}$ \\
\hline Shanghai & $0.06(2.96)^{* * *}$ & $7.64(3.03)^{* * *}$ \\
\hline Jiangsu & $0.38(10.68)^{* * *}$ & $2.46(9.46)^{* * *}$ \\
\hline Zhejiang & $0.21(12.40)^{* * *}$ & $4.49(12.40)^{* * *}$ \\
\hline Anhui & $0.49(7.12)^{* * *}$ & $1.79(6.18)^{* * *}$ \\
\hline Fujian & $0.25(7.59)^{* * *}$ & $3.36(7.10)^{* * *}$ \\
\hline Jiangxi & $0.4(8.68)^{* * *}$ & $2.25(9.82)^{* * *}$ \\
\hline Shandong & $0.47(26.06)^{* * *}$ & $2.07(26.30)^{* * *}$ \\
\hline Henan & $0.55(6.24)^{* * *}$ & $1.43(6.09)^{* * *}$ \\
\hline Hubei & $0.49(15.21)^{* * *}$ & $1.92(18.20)^{* * *}$ \\
\hline Hunan & $0.73(10.38)^{* * *}$ & $1.25(13.28)^{* * *}$ \\
\hline Guangdong & $0.17(10.82)^{* * *}$ & $5.35(10.32)^{* * *}$ \\
\hline Guangxi & $0.47(11.57)^{* * *}$ & $2.03(12.95)^{* * *}$ \\
\hline Hainan & $0.16(6.33)^{* * *}$ & $4.64(4.37)^{* * *}$ \\
\hline Chongqing & $1.00(7.45)^{* * *}$ & $0.79(8.68)^{* * *}$ \\
\hline Sichuan & $0.56(13.76)^{* * *}$ & $1.71(15.10)^{* * *}$ \\
\hline Guizhou & $0.71(8.30)^{* * *}$ & $1.20(7.32)^{* * *}$ \\
\hline Yunnan & $0.4(25.37)^{* * *}$ & $2.44(26.42)^{* * *}$ \\
\hline Tibet & $0.04(1.43)$ & $5.40(2.78)^{* * *}$ \\
\hline Shaanxi & $0.33(6.17)^{* * *}$ & $2.22(5.19)^{* * *}$ \\
\hline Gansu & $0.28(8.54)^{* * *}$ & $3.08(8.76)^{* * *}$ \\
\hline Qinghai & $0.21(3.63)^{* * *}$ & $2.82(4.00)^{* * *}$ \\
\hline Ningxia & $0.63(7.45)^{* * *}$ & $1.31(7.59)^{* * *}$ \\
\hline Xinjiang & $0.45(1.53)$ & $0.51(2.05)^{* *}$ \\
\hline Panel & $0.43(49.55)^{* * *}$ & $2.59(51.45)^{* * *}$ \\
\hline Eastern & $0.28(32.54)^{* * *}$ & $3.71(32.18)^{* * *}$ \\
\hline Central & $0.60(26.51)^{* * *}$ & $1.59(26.02)^{* * *}$ \\
\hline Western & $0.46(26.44)^{* * *}$ & $2.15(27.79)^{* * *}$ \\
\hline
\end{tabular}


Table 4 provides results of the panel causality test. In the short-run, we find evidence that housing price has a significant effect on divorce in the full sample and the eastern and central subsamples, implying short-run causality between housing price and divorce. However, for the long-run, we find that divorce is positive and significant at the $1 \%$ level, confirming the long-run effect of divorce on housing price in the full sample. The positive effect of divorce on housing price are also found in the eastern region, but not for the central and western regions, which might be due to housing prices in the western region being too low to allow divorce to make a difference. Interestingly, there is a long-run causality relationship from housing price to divorce in the central region. A possible reason for this is that a rapid increase in housing price makes selling a house easier in the central region and decreases the cost of divorce (Genesove and Mayer, 1997). Another reason may be that house-purchase restrictions in China force some families to divorce to buy more houses (Du and Zhang, 2015). Moreover, we see that there is a one-way causal relation running from divorce to housing price.

Table 4.

\section{Panel Causality Tests}

The table reports the results from the panel causality tests. $\times$ denotes there is no causal relationship, and + denotes there exists a positive causal relationship. Hprice denotes housing price. ${ }^{* * *}$, ${ }^{* *}$, and "denote statistical significance at the $1 \%, 5 \%$, and $10 \%$ levels, respectively. The parameters $\lambda$ are the error-correction terms to examine the long-run relationship.

\begin{tabular}{llcccc}
\hline & Dependent & \multicolumn{4}{c}{ Source of Causation (Divorce or Hprice) } \\
\cline { 2 - 6 } & Variable & Full & Eastern & Central & Western \\
\hline \multirow{3}{*}{ Short-run } & $\Delta$ Divorce & + & + & + & $\mathrm{x}$ \\
\cline { 2 - 5 }$\lambda$ & $\Delta$ Hprice & $\mathrm{x}$ & $\mathrm{x}$ & $\mathrm{x}$ & $\mathrm{x}$ \\
& $\Delta$ Divorce & 0.863 & -1.629 & $2.715^{* * *}$ & 0.113 \\
\multirow{3}{*}{ Long-run } & $\Delta$ Hprice & $8.619^{* * *}$ & $4.875^{* * *}$ & 0.686 & $-1.899^{*}$ \\
& $\Delta$ Divorce & + & + & + & $\mathrm{x}$ \\
& $\Delta$ Hprice & + & + & $\mathrm{x}$ & + \\
\hline
\end{tabular}

The above results confirm the cointegration relationship between housing price and divorce in 31 provinces of China. To enhance the reliability of our results, we further use residential housing price per square meter (RHprice) as the proxy variable to re-examine the cointegration relationship. Based on the statistics rules of the National Bureau of Statistics, the commercial property house is divided into three categories, including residential buildings, office buildings, and housing for business uses. Because the price of residential buildings is more relevant to people's lives and thus their decisions on marriage, we employ it to check the robustness of the cointegration relationship.

Table 5 presents the results of a panel unit root test for RHprice. It is clear that RHprice exhibits a significant I(1) process, showing that RHprice and Divorce follow similar paths. Using these results, we thus test for RHprice and Divorce to determine whether there is a long-run cointegrated relation. The panel cointegration test results are provided in Table 6 . All statistics express similar significance as those in Table 2, meaning that a long-run cointegration relationship not only exists in the full sample, but also in the three subsamples. Once the cointegration relationship 
is supported, we use FMOLS to determine the specific influence. Table 7 gives the robust province-by-province results and the panel FMOLS estimators. As shown at the bottom of Table 7, all panel parameters are statistically significant at the $1 \%$ level and positive, whether in the full sample or the three subsamples. On a provincial basis, housing price has a significantly positive effect on divorce, and reverse causality is also discovered. When the dependent variable is Divorce, in 30 of 31 provinces (except for Tibet) RHprice has a significantly positive effect on Divorce, whereas when the dependent variable is Divorce, in all provinces the divorce rate has a significantly positive effect on $R$ Hprice.

Table 5 .

Panel Unit Root Tests for RHprice

The table reports the panel unit root tests of RHprice. LLC, Breitung and IPS tests represent Levin et al. (2002), Breitung (2000) and Im et al. (2003) panel unit root tests, respectively, which are under the null of without a unit root. $\Delta$ denotes first differences. *** indicates statistical significance at the $1 \%$ level.

\begin{tabular}{lccc}
\hline Variable & LLC & Breitung & IPS \\
\hline RHprice & 4.78 & 7.412 & 11.442 \\
$\Delta$ RHprice & $-5.650^{* * *}$ & $-9.293^{* * *}$ & $-8.720^{* * *}$ \\
\hline
\end{tabular}

Table 6.

\section{Additional Panel Cointegration Tests}

The table shows results of the additional panel cointegration tests for robustness. These statistics are from Pedroni's (2004) except for Westerlund that is from Westerlund (2005). Statistics are asymptotically distributed as normal. The variance ratio test is right-sided, while the others are left-sided. RHprice denotes residential housing price. ${ }^{* * *+*},{ }^{* *}$, and ${ }^{*}$ denote rejecting the null of no cointegration at the $1 \%, 5 \%$, and $10 \%$ levels, respectively.

\begin{tabular}{lcccc}
\hline \multirow{2}{*}{ Variable } & \multicolumn{4}{c}{ Dependent Variable: RHprice } \\
\cline { 2 - 5 } & Full Sample & Eastern & Central & Western \\
\hline Panel variance & 1.232 & 1.352 & $3.080^{* * *}$ & $2.909^{* * *}$ \\
Panel r & 1.308 & 1.367 & -0.278 & -0.405 \\
Panel PP & $-2.062^{* * *}$ & -0.275 & $-3.666^{* * *}$ & $-4.333^{* * *}$ \\
Panel ADF & $-3.796^{* * *}$ & -1.35 & $-3.602^{* * *}$ & $-4.207^{* * *}$ \\
Group r & $3.170^{* * *}$ & $2.433^{* *}$ & 0.819 & 0.995 \\
Group PP & $-1.885^{*}$ & -1.315 & $-4.289^{* * *}$ & $-3.903^{* * *}$ \\
Group ADF & $-2.801^{* * *}$ & $-1.990^{* *}$ & $-3.680^{* * *}$ & $-3.743^{* * *}$ \\
Westerlund & $-1.660^{* *}$ & $-1.464^{*}$ & -0.693 & -0.661 \\
\hline
\end{tabular}


Table 7.

\section{Additional FMOLS Long-Run Estimates}

The table shows the additional FMOLS long-run estimates. RHprice denotes residential housing price. ${ }^{* * *}$, ${ }^{* *}$, and ${ }^{*}$ denote rejecting the null of no cointegration at the $1 \%, 5 \%$, and $10 \%$ levels, respectively.

\begin{tabular}{|c|c|c|}
\hline Province & $\begin{array}{c}\text { Dependent Variable: } \\
\text { Divorce }\end{array}$ & $\begin{array}{c}\text { Dependent Variable: } \\
\text { RHprice }\end{array}$ \\
\hline Beijing & $0.08(2.33)^{* *}$ & $5.45(2.30)^{* *}$ \\
\hline Tianjin & $0.24(5.94)^{* * *}$ & $3.40(5.38)^{* * *}$ \\
\hline Hebei & $0.44(7.87)^{* * *}$ & $2.07(9.25)^{* * *}$ \\
\hline Shanxi & $0.32(7.26)^{* * *}$ & $2.58(6.84)^{* * *}$ \\
\hline Inner Mogolia & $0.69(5.64)^{* * *}$ & $1.13(4.94)^{* * *}$ \\
\hline Liaoning & $0.51(9.43)^{* * *}$ & $1.59(9.66)^{* * *}$ \\
\hline Jilin & $0.93(5.74)^{* * *}$ & $0.80(7.21)^{* * *}$ \\
\hline Heilongjiang & $0.91(13.57)^{* * *}$ & $1.02(14.13)^{* * *}$ \\
\hline Shanghai & $0.06(3.07)^{* * *}$ & $8.26(3.26)^{* * *}$ \\
\hline Jiangsu & $0.39(12.03)^{* * *}$ & $2.44(10.92)^{* * *}$ \\
\hline Zhejiang & $0.21(11.35)^{* * *}$ & $4.64(11.48)^{* * *}$ \\
\hline Anhui & $0.50(7.00)^{* * *}$ & $1.76(6.03)^{* * *}$ \\
\hline Fujian & $0.23(6.82)^{* * *}$ & $3.46(6.25)^{* * *}$ \\
\hline Jiangxi & $0.40(9.53)^{* * *}$ & $2.27(10.68)^{* * *}$ \\
\hline Shandong & $0.49(24.39)^{* * *}$ & $1.98(23.99)^{* * *}$ \\
\hline Henan & $0.60(6.27)^{* * *}$ & $1.33(6.31)^{* * *}$ \\
\hline Hubei & $0.49(17.96)^{* * *}$ & $1.93(22.38)^{* * *}$ \\
\hline Hunan & $0.78(11.87)^{* * *}$ & $1.18(15.62)^{* * *}$ \\
\hline Guangdong & $0.17(10.45)^{* * *}$ & $5.42(10.07)^{* * *}$ \\
\hline Guangxi & $0.48(12.7)^{* * *}$ & $1.97(13.93)^{* * * *}$ \\
\hline Hainan & $0.15(5.97)^{* * *}$ & $4.57(4.07)^{* * *}$ \\
\hline Chongqing & $1.01(10.04)^{* * *}$ & $0.83(11.27)^{* * *}$ \\
\hline Sichuan & $0.56(11.82)^{* * *}$ & $1.72(11.81)^{* * *}$ \\
\hline Guizhou & $0.73(5.18)^{* * *}$ & $0.96(4.17)^{* * *}$ \\
\hline Yunnan & $0.45(22.39)^{* * *}$ & $2.14(24.03)^{* * *}$ \\
\hline Tibet & $0.03(1.19)^{* * *}$ & $5.14(2.55)^{* * *}$ \\
\hline Shaanxi & $0.35(5.98)^{* * *}$ & $2.12(4.96)^{* * *}$ \\
\hline Gansu & $0.29(6.70)^{* * *}$ & $2.91(6.87)^{* * *}$ \\
\hline Qinghai & $0.22(2.54)^{* *}$ & $1.87(2.49)^{* *}$ \\
\hline Ningxia & $0.67(9.07)^{* * *}$ & $1.27(8.93)^{* * *}$ \\
\hline Xinjiang & $0.50(1.68)^{*}$ & $0.56(2.77)^{* * *}$ \\
\hline Panel & $0.45(49.18)^{* * *}$ & $2.54(51.11)^{* * *}$ \\
\hline Eastern & $0.29(32.43)^{* * *}$ & $3.77(31.92)^{* * *}$ \\
\hline Central & $0.63(28.29)^{* * *}$ & $1.56(31.38)^{* * *}$ \\
\hline Western & $0.48(24.22)^{* * *}$ & $1.95(25.25)^{* * *}$ \\
\hline
\end{tabular}


Table 8 provides results from the panel causality test. For the short-run, we find evidence that housing price has a significant effect on divorce in the full sample and the eastern region. For the long-run, the causality running from divorce to residential housing price is found in the full sample and the eastern region. Similarly, residential housing price (RHprice) has a long-run positive effect on divorce in the central region, but a negative effect in the eastern region. In the western region, we find no causality between divorce and residential housing price. Overall, the cointegration relationship between housing price and divorce exists when we use the alternative variable RHprice.

Table 8.

\section{Additional Panel Causality Tests}

The table shows the additional panel causality tests. $\times$ denotes there is no causal relationship, and + denotes there exists a positive causal relationship. RHprice denotes residential housing price. ${ }^{* *+*}, "$, and "denote statistical significance at the $1 \%, 5 \%$, and $10 \%$ levels, respectively. The parameters $\lambda$ are the error-correction terms to examine the long-run relationship

\begin{tabular}{llcccc}
\hline & Dependent & \multicolumn{4}{c}{ Source of Causation (Divorce or RHprice) } \\
\cline { 2 - 6 } & Variable & Full & Eastern & Central & Western \\
\hline \multirow{3}{*}{ Short-run } & $\Delta$ Divorce & + & + & $\mathrm{x}$ & $\mathrm{x}$ \\
\cline { 2 - 6 }$\lambda$ & $\Delta$ RHprice & $\mathrm{x}$ & $\mathrm{x}$ & $\mathrm{x}$ & $\mathrm{x}$ \\
& $\Delta$ Divorce & 0.834 & $-1.729^{*}$ & $2.632^{* * *}$ & 0.213 \\
\multirow{3}{*}{ Long-run } & $\Delta$ RHprice & $10.084^{* * *}$ & $5.672^{* * *}$ & 1.124 & -0.942 \\
& $\Delta$ Divorce & + & + & $\mathrm{x}$ & $\mathrm{x}$ \\
& $\Delta$ RHprice & + & + & $\mathrm{x}$ & $\mathrm{x}$ \\
\hline
\end{tabular}

\section{CONCLUSION}

Employing data for 31 Chinese provinces over the period 1997-2015, we examine long-run co-movement and causality of housing price and divorce based on the cointegration test method proposed by Pedroni (2004) and Westerlund (2005) and the panel VECM. The results show that housing price and divorce follow a I(1) process and move together in the long-run for the full sample and the three subsamples. The FMOLS estimation also suggests a positive long-run effect among variables. Moreover, the panel VECM confirms short-run, positive causality running from housing price to divorce in the full sample, and for the eastern and central regions, and a long-run positive causal relation running from divorce to housing price in the full sample and the eastern region. Interestingly, there is longrun positive causality running from housing price to divorce in the central region, meaning that housing price has a positive effect on divorce in the central region not only for the short-run, but also for the long-run. We also check whether our results are sensitive to the measure of housing price by resorting to an alternative proxy, residential housing price. The results are in line with our earlier findings, supporting the cointegration relationship between housing price and divorce in China.

Overall, our results confirm the cointegration relationship between housing price and divorce, specifically short-run causality from housing price to divorce and long-run causality from divorce to housing price. The implication is that, in 
the short-run, regulation of housing price can decrease the rate of divorce and help the stability of society. This research also has some limitations. For instance, the cointegration tests proposed by Pedroni (2004) and Westerlund (2005) cannot address the problem of cross-sectional dependence of variables, which calls for more powerful statistical methods. Additionally, future research could use more disaggregated data to investigate decisions on divorce. In short, our study adds to the debate on the relationship between housing price and divorce.

\section{REFERENCES}

Attanasio, O., Leicester, A., and Wakefield, M. (2011). Do House Prices Drive Consumption Growth? The Coincident Cycles of House Prices and Consumption in the UK. Journal of the European Economic Association, 9, 399-435.

Battu, H., Brown, H., and Costa-Gomes, M. (2013). Not Always for Richer or Poorer: The Effects of Income Shocks and House Price Changes on Marital Dissolution. Working Paper, 1-20.

Becker, G. S., Landes, E. M., and Michael, R. T. (1977). An Economic Analysis of Marital Instability. Journal of Political Economy, 85, 1141-1187.

Boheim, R., and Ermisch, J. (2001). Partnership Dissolution in the UK--the Role of Economic Circumstances. Oxford Bulletin of Economics and Statistics, 63, 197208.

Breitung, J. (2000). The Local Power of Some Unit Root Tests for Panel Data. Advances in Econometrics, 15, 161-178.

Chang, C., and Lee, C. (2010). A Re-Examination of German Government Approval and Economic Performance: Is There a Stable Relationship between Them?. International Economic Journal, 24, 25-43.

Chang, C., and Lee, C. (2015). Do Oil Spot and Futures Prices Move Together?. Energy Economics, 50, 379-390.

Chang, C., Lee, C., and Berdiev, A. (2015). The Impact of Government Ideology on Energy Efficiency: Evidence from Panel Data. Energy Efficiency, 8, 1181-1199.

Chang, C., Lee, C., and Hsieh, M. (2011). Globalization, Real Output, and Multiple Structural Breaks. Global Economic Review, 40, 421-444.

Dieleman, F. M., and Schouw, R. J. (1989). Divorce, Mobility and Housing Demand. European Journal of Population, 5, 235-252.

Du, Z., and Zhang, L. (2015). Home-Purchase Restriction, Property Tax and Housing Price in China: A Counterfactual Analysis. Journal of Econometrics, 188, 558-568.

Engle, R. F., and Granger, C. W. J. (1987). Co-Integration and Error Correction: Representation, Estimation, and Testing. Econometrica, 55, 251-276.

Fan, Z., and Hu, X. (2015). Unexpected House-Price Fluctuations and Marital Dissolution. Journal of Huazhong University of Science and Technology (Scocial Science Edition), 29, 110-117. (in Chinese)

Farnham, M., Schmidt, L., and Sevak, P. (2011). House Prices and Marital Stability. The American Economic Review, 101, 615-619.

Farzanegan, M. R., and Gholipour, H. F. (2016). Divorce and the Cost of Housing: Evidence from Iran. Review of Economics of the Household, 14, 1029-1054. 
Fereidouni, H. G. (2016). Housing Costs and Divorce Rate in the MENA Countries. Topics in Middle Eastern and North African Economies, 18.

Genesove, D., and Mayer, C. J. (1997). Equity and Time to Sale in the Real Estate Market. The American Economic Review, 87, 255-269.

Harknett, K., and Schneider, D. (2012). Is a Bad Economy Good for Marriage? The Relationship between Macroeconomic Conditions and Marital Stability from 1998-2009. Working Paper, 1-30.

Im, K. S., Pesaran, M. H., and Shin, Y. (2003). Testing for Unit Roots in Heterogeneous Panels. Journal of Econometrics, 115, 53-74.

Jang, C., and Chang, C. (2014). National Income and Fishery Consumption: A Global Investigation. Economic Research - Ekonomska Istraživanja, 27, 15-33.

Klein, J. (2017). House Price Shocks and Individual Divorce Risk in the United States. Journal of Family E Economic Issues, 38, 628-649.

Levin, A. T., Lin, C. and Chu, C. J. (2002). Unit Root Tests in Panel Data: Asymptotic and Finite-Sample Properties. Journal of Econometrics, 108, 1-24.

Li, L., and Wu, X. (2014). Housing Price and Entrepreneurship in China. Journal of Comparative Economics, 42, 436-449.

Li, P., and Xu, J. (2012). Housing Price and Fertility Rate. China Economic Journal, 5, 97-111.

Li, Q., and Chand, S. (2013). House Prices and Market Fundamentals in Urban China. Habitat International, 40, 148-153.

Li, S., Whalley, J. and Zhao, X. (2013). Housing Price and Household Savings Rates: Evidence from China. Journal of Chinese Economic and Business Studies, 11, 197-217.

Liang, W., Lu, M., and Zhang, H. (2016). Housing Prices Raise Wages: Estimating the Unexpected Effects of Land Supply Regulation in China. Journal of Housing Economics, 33, 70-81.

Mused, A. (2009). Another Look at Wealth and Marital Relationships:The Effects of House Prices on Divorce Rates. Working Paper, 1-28.

Pedroni, P. (2000). Fully Modified OLS for Heterogeneous Cointegrated Panels. Advances in Econometrics, 15, 1-20.

Pedroni, P. (2004). Panel Cointegration: Asymptotic and Finite Sample Properties of Pooled Time Series Tests with an Application to the PPP Hypothesis. Econometric Theory, 20, 597-625.

Peteke, F., and Maarten, V. H. (2010). The Impact of Splitting up and Divorce on Housing Careers in the UK. Housing Studies, 25, 483-507.

Rainer, H., and Smith, I. (2010). Staying Together for the Sake of the Home? House Price Shocks and Partnership Dissolution in the UK. Journal of The Royal Statistical Society Series A-statistics in Society, 173, 557-574.

Wang, Q., and Zhou, Q. (2010). China's Divorce and Remarriage Rates: Trends and Regional Disparities. Journal of Divorce E Remarriage, 51, 257-267.

Wang, X. (2018). Divorce and Housing Price -Analysis Based on Instrument Variable Method. China Price, 58-61.

Wen, J., Yang, X., Feng, G., Sui, B., and Chang, C.P. (2017). The Comovement Between Venture Capital and Innovation in China: What Are The Implications?. Quality E Quantity, 51, 2489-2506. 
Wei, S. and Zhang, X. (2011). The Competitive Saving Motive: Evidence from Rising Sex Ratios and Savings Rates in China. Journal of Political Economy, 119, 511-564.

Wei, S., Zhang, X., and Liu, Y. (2017). Home Ownership as Status Competition: Some Theory and Evidence. Journal of Development Economics, 127, 169-186.

Weiss, Y., and Willis, R. J. (1997). Match Quality, New Information, and Marital Dissolution. Journal of Labor Economics, 15, 293-329.

Westerlund, J. (2005). New Simple Tests for Panel Cointegration. Econometric Reviews, 24, 297-316.

Yu, W., and Zhou, W. (2015). The Research on Housing Price and Marital Stability in China. Statistics \& Decision, 24, 83-86. (in Chinese)

Zhang, C., An, G., and Yu, X. (2012). What Drives China's House Prices: Marriage or Money?. China \& World Economy, 20, 19-36. 


\section{Appendix}

Table A1.

Descriptive Statistics

The table shows the descriptive statistics of the variables, Divorce and Hprice, for the period of 1997 to 2015. Divorce and Hprice denote divorce and housing price, respectively. Min and Max denote minimum and maximum, respectively.

\begin{tabular}{lccccc}
\hline Variables & Observation & Mean & $\begin{array}{c}\text { Standard } \\
\text { Deviation }\end{array}$ & Min & Max \\
\hline Divorce & 589 & 6.855 & 5.335 & 0.050 & 28.620 \\
Hprice & 589 & 3.581 & 2.972 & 0.138 & 22.633 \\
\hline
\end{tabular}

